\title{
GRAMMATICAL ERRORS IN THESIS ABSTRACTS WRITTEN BY THE UNDERGRADUATE STUDENTS OF MANAGEMENT STUDY PROGRAM
}

\author{
Soraya Grabiella Dinamika \\ Sekolah Tinggi Ilmu Manajemen Sukma Medan, Indonesia \\ Corresponding email: dinamika.soraya@gmail.com
}

\begin{abstract}
This research aims at analyzing the grammatical errors in English abstracts of the undergraduate thesis. This research takes place at two private colleges in Medan city which provide the undergraduate program of management study namely Sekolah Tinggi Ilmu Manajemen Sukma Medan and Sekolah Tinggi Ilmu Ekonomi Eka Prasetya. There are 20 abstracts taken as the data which are gathered from those colleges. This research engages with a qualitative descriptive approach. The data were analyzed by using the Error Analysis Method by Gass and Selinker. Based on the analysis, the categories of the grammatical errors found are the subject-verb agreement in the use of tense agreement and number agreement, and the use of the article 'a/an/the'. The research findings show that the tense agreement error is 80 , the number agreement error is 10 , the omission of article a/an is 4 ,

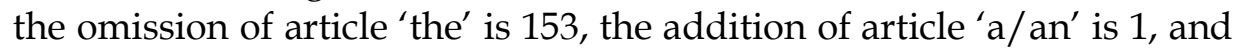
the addition of article 'the' is 8 . Hence, there are 300 grammatical errors found. Meanwhile, there are two sources of the grammatical errors; they are inter-language error and intra-language error. Yet, four factors cause grammatical error namely indeterminacy, inconsistency, simplification, and overgeneralization. Based on the findings, the researcher gives constructive pedagogical remediation which is directed to the EFL learners, English language instructor, and the syllabus developer.
\end{abstract}

Keywords: grammatical error, error analysis, undergraduate thesis abstract, private college

\section{INTRODUCTION}

As one of the categories of high education facilities, a college requires the students to write a final research report, which is generally called as a thesis. 
A thesis is commonly written by the students who take a certain major or graduate program as a requirement of finishing all the courses which have been selected and a key to graduate.

In writing a thesis, one needs to pay attention to the main body of scientific writing, such as the background of the study, research question, and review of literature, research methodology, data analysis, finding, conclusion, and suggestion. Yet, one of the most important things of all is an abstract. Porte (2002:3) states that for the author, the principal aim of the abstract is to summarize the most important points of the paper. In other words, the abstract contains a concise description of the whole result of the research. The abstracts are the main method which is used to communicate research findings and contributions to the works of the field studied. Generally, a researcher has to prepare an abstract after completing his research thesis or report (Singh, 2006:257). Yuned, et.al (2015:95) state that a good abstract must be created by the writers as worth as the whole content of the research article to be able to represent what messages want to be expressed in the abstract. The abstract allows readers who may be interested in the paper to quickly decide whether it is relevant to their purposes and whether they need to read the whole paper.

Along with the development of the modern education, most of the national colleges and universities in Indonesia have formulated compulsory regulation for the students to write the bilingual abstract in their thesis within the Indonesian language and the English language. For instance, the private colleges in Medan City such as Sekolah Tinggi Ilmu Manajemen Sukma and Sekolah Tinggi Ilmu Ekonomi Eka Prasetya apply this regulation to their graduate candidates as well. Principally, an abstract is written by using the standard form of a language, so is in the English language. So that the use of standardized English grammar needs to be supervised, for it has a quite different language structure to the Indonesian language, in which it may cause an error in the grammar use.

The English language is one of the basic courses in the college or university in Indonesia, but the students who speak English as a foreign language, are proven to remain writing an incorrect form of English language, either in the form of morphology level or even syntax level. Kusumawardhani (2017:84) finds in her research that the English language foreign learners still make errors of omission because of the lack of knowledge of the language grammar. They make errors in the omission of the preposition 'of', auxiliary, article, countable and uncountable noun, and apostrophe. Merizawati (2018:71), in her research, finds that 124 EFL learners in IAIN Bengkulu make errors in the paper presentation of the semantic and pragmatic course and the questionnaire sheet. From these two instruments of collecting data, she obtains 22 types of errors are made by the 
EFL learners. Moreover, Dinamika and Hanafiah (2019:120) find that the students of the English Department of University of Sumatera Utara make numbers of syntactical error within the use of article 'a/an',' the' in terms of omission and addition of articles, the use of the relative pronoun, and the use of subject-verb agreement in terms of the past tense agreement and number agreement. The research results show that the most predominant syntactical error is in the use of the article. Meanwhile, it has been commonly known that an article is a unit of part of speech that must have been learned as the basis of English grammar. Meanwhile, a research which is conducted by Burhanuddin (2020:30) reveals a vast number of errors in the questionnaire instruments which are written by students of the English Department of IAIN Pekalongan. There are eleven types of errors, the students make, namely verbs, articles, spelling, adjectives, preposition, sentence structure and order, word formation, word selection, noun, pronoun, and ambiguous communication.

Those research findings reinforce the assumption that college students may also make the English grammatical errors in their undergraduate thesis abstracts. Besides, a vast number of undergraduate theses must have also produced the same number of abstracts. But there is none of the research has been done to expose the phenomenon of English grammatical errors in the abstracts. So forth, this type of research is necessary to be done. It causes an impact on the number of graduates' research publications, and their interests in publishing the research. Meanwhile, a quality undergraduate thesis can compete in the national or even international indexed journal publication, which is possible to increase the scientific value of the research itself.

On purpose to improve the quality of college graduates in Medan city, particularly in the field of research and scientific writing publication, it is necessary to analyze English grammatical error in two colleges which hold the undergraduate program of management studies. They are Sekolah Tinggi Ilmu Manajemen Sukma Medan and Sekolah Tinggi Ilmu Ekonomi Eka Prasetya. However, there must be an appropriate method of analysis to be used. Thus, Error Analysis (EA) method is the answer. It is a method that was developed by the linguists by the late 70s to contrast the issue of first language and second language application. Error analysis aims at telling us something about the psycholinguistic processes of language learning. In this sense, Error Analysis is part of the methodology of the psycholinguistic investigation of language learning (Corder, 1981:35). Gass and Selinker (2008:102) define Error Analysis as a type of linguistic analysis that focuses on the errors learners make. It provides windows onto a system that is, evidence of the state of a learner's knowledge of the L2. The sources of error may happen because of the negative interference of the first language (inter- 
language) or the lack of knowledge of second language structure (intralanguage). Richards (1972:69) states that inter-language error is caused by the interference (negative transfer) of the learners' mother tongue. Meanwhile, the intra-language error refers to items produced by the learner which reflect not the structure of the mother tongue, but generalizations based on partial exposure to the target language.

The theory of EA currently has been expanded and modified by numbers of linguists, as it has a large scope of language issues that can be analyzed. Therefore, various researches on EA have increased quickly. Yet, in this research, a theory of EA arranged by Gass and Selinker is occupied, because it provides the teacher and learner a board of procedures which is suitable to use in the EFL classroom type, like in Indonesia. By seeing the purposes above, then this research also aims to; find out the category of the English grammatical in the undergraduate thesis abstracts written by the students of management studies major in private colleges of Medan City; to find out the factors that cause the errors, and to give the remedial action on the problematic areas.

\section{METHODS}

This research was conducted by using a descriptive qualitative approach. A qualitative approach is important in the area of educational research. So forth, the results of the analysis are going to be expressed descriptively which aims to present the comparison of the error and non-error language use.

\section{Subject}

The subject of this research was the private colleges that actively registered at LLDIKTI Region-I in the academic year of 2018/2019. The criteria of colleges that are being the location of the research are; 1) those which hold a regular undergraduate program of management studies major in Medan City; 2) accredited as B ranking at least; and 3) apply the rules of writing an abstract within Indonesian language and English language. After observing and selecting the colleges that hold those criteria, the locations of the research are directed to Sekolah Tinggi Ilmu Manajeman Sukma at Jl. Sakti Lubis No. 80 Medan and Sekolah Tinggi Ilmu Ekonomi Eka Prasetya at Jl. Merapi No. 8 Medan.

\section{Data \& Data Source}

The source of data was the undergraduate English thesis abstract of the students who take the management studies major and have graduated during the academic year of 2018/2019. The abstracts are selected by using the purposive sampling technique, where the researcher chooses only ten 
representative abstracts from each college that fulfill the criteria that have been set initially. Moreover, the data of this research are the English words or clause in the abstracts which contain the grammatical errors. The types of grammatical errors are classified into the use of subject-verb agreement (SVA) and the use of the article 'a/an/the'.

\section{Data Analysis Procedure}

In analyzing the grammatical error analysis, the researcher employs the EA procedures which have been arranged by Gass and Selinker. The procedures are going to be undergone respectively as followings; 1 ) to collect the data, 2) to identify the errors, 3) to classify the category of errors, 4) to count the number of errors, 5) to analyze the source of errors, and 6) to give remedial action. The figure below describes the EA procedures which are taken in this research.

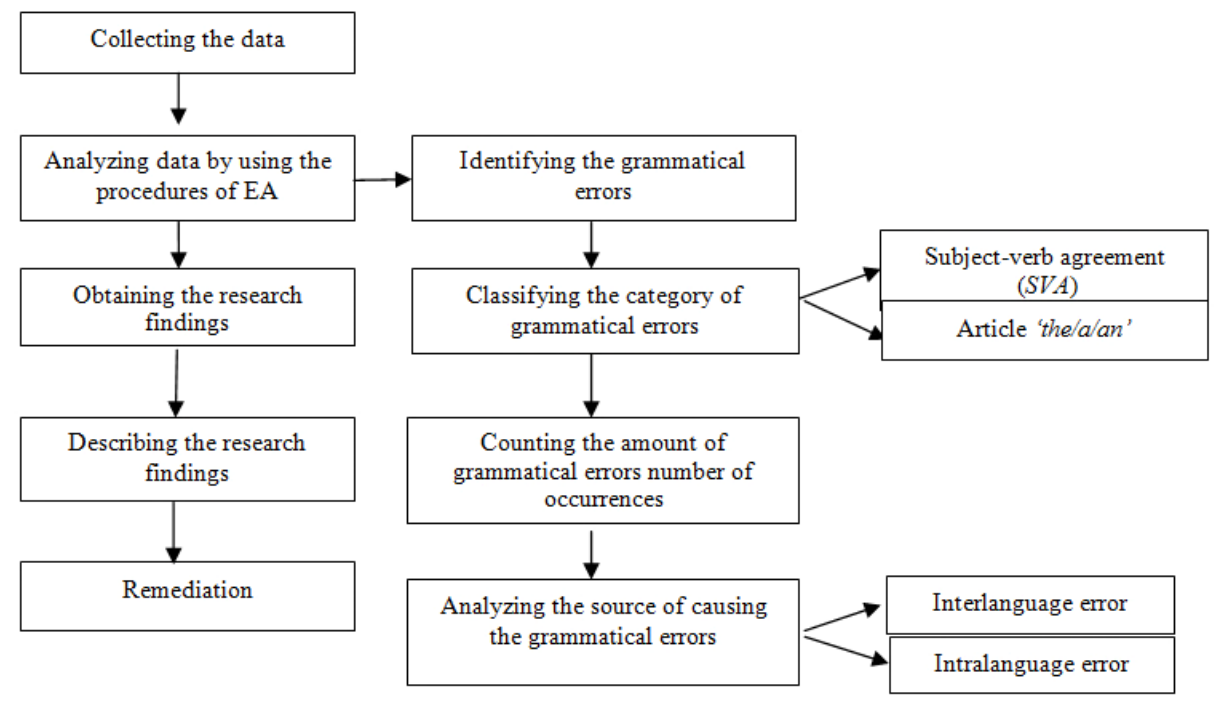

Figure 1 Error Analysis procedure

By following the first procedure of analysis, the researcher collects the data which are in the form of undergraduate thesis abstract written in the English language. After collecting the data, then the researcher continues the next procedure, identifying the grammatical error. In identifying the error, the researcher attempts to classify the error into which category it belongs to, whether to the use of SVA error or the article error. After the data is categorized, then the researcher attempts to count the amount of grammatical error which occurs according to its type of categories. This counting aims at presenting the data in the quantitative form. Mackey \& Gass (2005:182) argue that quantification in qualitative research has a different function as in quantitative research is. Quantification can play a role in both the generation of hypotheses and the verification of patterns that 
have been noticed; it can also be used later for data reporting. Therefore, it is still qualitative research. After the numbers of errors are obtained, then the researcher continues to define the source that causes the error, whether it is caused by inter-language error or intra-language error. This stage is important to take, for finding out what action should be applied to overcome a certain error. Besides, this stage also supports the remediation step which will be suggested. After the five EA procedures are applied, then the findings of the results are presented in the form of a table, to ease the researcher in noting the process of analysis and the reader to understand the process of analysis, later on. Remediation, as the last procedure is taken out by the researcher to give possible contributions to amending the way of EFL students and teachers in the process of teaching and learning the English language.

Besides, however, after all of the data are analyzed and explained, the factors that cause the errors are explained as well. They are inconsistency, indeterminacy, simplification, and overgeneralization. Inconsistency refers to the inability of L2 learners to keep in using a consistent form of L2 structure. Selinker in Richards (1972: 38) explains that overgeneralization is a phenomenon where one form of grammar is extended to an environment in which it could logically apply, but should not. Selinker in Touchie (1986:78) refers simplification to the simple forms and construction which often chosen by learners instead of more complex ones. Gass \& Selinker (2008:65) refers indeterminacy to the incomplete (or lack of) knowledge a learner has of parts of the second language grammar.

\section{FINDINGS}

The entire collection of the data has been analyzed by using the EA procedures. The amount of grammatical errors in the category of SVA and article use has been obtained as well. Therefore, this research has come to result in several findings. This section aims at presenting the result of the analysis in a clearer sight. The sub-section below shows the way the data are analyzed.

\section{Teacher's instructional strategies}

The result of the SVA error analysis shows that the main errors found are in the form of the number agreement and the tense agreement. The two subjects of research have also revealed way too different results. Table 1 below presents the example of SVA error found in the abstracts of Sekolah Tinggi Ilmu Manajemen Sukma Medan. 
Table 1: Subject-verb agreement error - STIM Sukma

\begin{tabular}{|c|c|c|c|c|c|}
\hline Initial & Category & Error Form & Amount & $\begin{array}{l}\text { Source \& } \\
\text { Cause }\end{array}$ & Correct Form \\
\hline \multirow[t]{3}{*}{ SRN } & $\begin{array}{l}\text { The use of } \\
\text { number } \\
\text { agreement }\end{array}$ & $\begin{array}{l}\text { The sample are } \\
\text { the financial } \\
\text { report of PT. } \\
\text { Agung } \\
\text { Podomoro Land } \\
\text { Tbk... }\end{array}$ & 1 & $\begin{array}{l}\text { Intra-language } \\
\text { error - } \\
\text { Indeterminacy } \\
\text { of number } \\
\text { agreement }\end{array}$ & $\begin{array}{l}\text { The sample is }{ }^{1} \text { the } \\
\text { financial report of } \\
\text { PT. Agung } \\
\text { Podomoro Land } \\
\text { Tbk... }\end{array}$ \\
\hline & \multirow[t]{2}{*}{$\begin{array}{l}\text { The use of } \\
\text { tense } \\
\text { agreement }\end{array}$} & $\begin{array}{l}\text { data analysis of } \\
\text { this research } \\
\text { using } 1 \\
\text { quantitative } \\
\text { descriptive } \\
\text { method... }\end{array}$ & 2 & $\begin{array}{l}\text { Intra-language } \\
\text { error - } \\
\text { Simplification in } \\
\text { using auxiliary } \\
\text { verb }\end{array}$ & $\begin{array}{l}\text { data analysis of } \\
\text { this research } \text { uses }^{1} \\
\text { quantitative } \\
\text { descriptive } \\
\text { method... }\end{array}$ \\
\hline & & $\begin{array}{l}\text {..while } \\
\text { managing data } \\
\text { using }{ }^{2} \text { SPSS } 20 .\end{array}$ & & $\begin{array}{l}\text { Intra-language } \\
\text { error - } \\
\text { Simplification in } \\
\text { using auxiliary } \\
\text { verb }\end{array}$ & $\begin{array}{l}\text {...while } \\
\text { managing data } \\
\text { uses }^{2} \text { SPSS } 20 .\end{array}$ \\
\hline
\end{tabular}

From the example above, it can be seen that the student SRN writes the auxiliary to be 'are' that is preceded by a singular noun 'the sample', grammatically, the correct to be that should be used is 'is' that indicates the singular noun. It is caused by his indeterminacy of using the number agreement, in which he knows that he should put an auxiliary to be after the subject, but he misses using the right one. Then, he makes errors in the tense agreement, where he writes the present participant without following by an auxiliary to be before. He should write 'is using' instead. These errors are caused by the simplification where he simplifies the use of auxiliary.

Table 2: Subject-verb agreement error - STIE Eka Prasetya

\begin{tabular}{|c|c|c|c|c|c|}
\hline Initial & Category & Error Form & Amount & $\begin{array}{l}\text { Source \& } \\
\text { Cause }\end{array}$ & Correct Form \\
\hline \multirow[t]{2}{*}{ FIN } & $\begin{array}{l}\text { The use of } \\
\text { number } \\
\text { agreement }\end{array}$ & $\begin{array}{l}\text { its observation } \\
\text { unit } \text { are }^{1} \\
\text { students from... }\end{array}$ & 1 & $\begin{array}{l}\text { Intra-language } \\
\text { error } \\
\text { Indeterminacy } \\
\text { of number } \\
\text { agreement }\end{array}$ & $\begin{array}{l}\text { its observation } \\
\text { unit is }{ }^{1} \text { students } \\
\text { from... }\end{array}$ \\
\hline & $\begin{array}{l}\text { The use of } \\
\text { tense } \\
\text { agreement }\end{array}$ & $\begin{array}{l}\text { the population } \\
\text { in this study } \\
\text { were }^{1,2} 811 \\
\text { respondents... }\end{array}$ & 3 & $\begin{array}{l}\text { Intra-language } \\
\text { error } \\
\text { Inconsistency in } \\
\text { using present } \\
\text { form }^{1} \\
\text { Indeterminacy } \\
\text { of number } \\
\text { agreement }^{2}\end{array}$ & $\begin{array}{l}\text { the population in } \\
\text { this study is }{ }^{1,2} 811 \\
\text { respondents... }\end{array}$ \\
\hline
\end{tabular}


Grammatical Errors in Thesis Abstracts Written by the Undergraduate Students of...

\begin{tabular}{|c|c|c|c|c|c|}
\hline Initial & Category & Error Form & Amount & $\begin{array}{c}\text { Source \& } \\
\text { Cause }\end{array}$ & Correct Form \\
\hline & & $\begin{array}{l}\text { the } \\
\text { technique...was } \\
\text { the Slovin } \\
\text { formula... }\end{array}$ & & $\begin{array}{l}\text { Intra-language } \\
\text { error } \\
\text { Inconsistency in } \\
\text { using present } \\
\text { form }\end{array}$ & $\begin{array}{l}\text { the } \\
\text { technique...is }{ }^{3} \text { the } \\
\text { Slovin formula... }\end{array}$ \\
\hline
\end{tabular}

The example above shows the errors made by student FIN, where she uses the aux. to be 'are' to follow a singular noun as the subject. She should use the aux. to be instead. It is caused by her indeterminacy in using number agreement of the English language structure. On the tense agreement use, she writes errors in the context of the text. She has begun writing her abstract in the context of present activities, therefore she should follow its initial pattern, but she doesn't do so. Therefore, it causes inconsistency of her writing's harmony.

Table 3: Article error - STIM Sukma

\begin{tabular}{|c|c|c|c|c|c|}
\hline Initial & Category & Error Form & Amount & Source \& Cause & Correct Form \\
\hline \multirow[t]{8}{*}{ RWU } & $\begin{array}{l}\text { Omission } \\
\text { of 'a/an' }\end{array}$ & $\begin{array}{l}\text {...growth has } \\
1,2,3 \text { positive } \\
\text { effect... }\end{array}$ & 3 & $\begin{array}{l}\text { Intra-language } \\
\text { error } \\
\text { Simplification by } \\
\text { omitting article } \\
\text { needed }\end{array}$ & $\begin{array}{l}\text {...growth has } \\
1,2,3 \text { a positive } \\
\text { effect... }\end{array}$ \\
\hline & $\begin{array}{l}\text { Omission } \\
\text { of 'the' }\end{array}$ & $\begin{array}{l}\text {...unemployment } \\
\text { in } 1,2,3,4,5 \text { North } \\
\text { Sumatera } \\
\text { Province. }\end{array}$ & 10 & $\begin{array}{l}\text { Intra-language } \\
\text { error } \\
\text { Simplification by } \\
\text { omitting article }\end{array}$ & $\begin{array}{l}\text {...unemployment } \\
\text { in } 1,2,3,4,5 \text { the North } \\
\text { Sumatera } \\
\text { Province. }\end{array}$ \\
\hline & & $\begin{array}{l}\text {...this research is } \\
{ }^{6} \text { Central Bureau of } \\
\text { Statistics and } \\
\text { 'Investment } \\
\text { Coordinating } \\
\text { Board... }\end{array}$ & & needed & $\begin{array}{l}\text {...this research is } \\
{ }^{6} \text { the Central } \\
\text { Bureau of } \\
\text { Statistics and }{ }^{7} \text { the } \\
\text { Investment } \\
\text { Coordinating } \\
\text { Board... }\end{array}$ \\
\hline & & $\begin{array}{l}{ }^{8} \text { Data analysis } \\
\text { used is... }\end{array}$ & & & $\begin{array}{l}{ }^{8} \text { the data analysis } \\
\text { used is... }\end{array}$ \\
\hline & & $\begin{array}{l}\text {..9hypothesis } \\
\text { testing using... }\end{array}$ & & & $\begin{array}{l}\ldots{ }^{9} \text { the hypothesis } \\
\text { testing using... }\end{array}$ \\
\hline & & $\begin{array}{l}\ldots{ }^{10} \text { Investment } \\
\text { has negative } \\
\text { effect... }\end{array}$ & & & $\begin{array}{l}\ldots{ }^{10} \text { the Investment } \\
\text { has negative } \\
\text { effect... }\end{array}$ \\
\hline & $\begin{array}{l}\text { Addition } \\
\text { of 'a/an' }\end{array}$ & 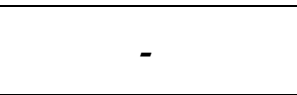 & - & - & 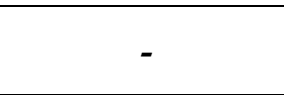 \\
\hline & $\begin{array}{l}\text { Addition } \\
\text { of 'the' }\end{array}$ & $\begin{array}{l}\text {...the } e^{1} \text { object of } \\
\text { the research... }\end{array}$ & 2 & $\begin{array}{l}\text { Intra-language } \\
\text { error }\end{array}$ & $\begin{array}{l}\ldots{ }^{1} \text { object of the } \\
\text { research... }\end{array}$ \\
\hline
\end{tabular}




\begin{tabular}{|c|c|c|c|c|c|}
\hline Initial & Category & Error Form & Amount & Source \& Cause & Correct Form \\
\hline & & $\begin{array}{l}\text {...that }{ }^{2} \text { the } \\
\text { partially } \\
\text { variable... }\end{array}$ & & $\begin{array}{l}\text { Overgeneralization } \\
\text { the use of article }\end{array}$ & $\begin{array}{l}\text {...that }{ }^{2} \text { partially } \\
\text { variable... }\end{array}$ \\
\hline
\end{tabular}

An example of an article error from student RWU above shows that he omits the use of the article ' $a / a n^{\prime}$ ' in the necessary place. It is caused by intra-language errors, in which he attempts at simplifying the use of the article by omitting it in the clause. Then, he makes several errors in the use of the article 'the', in which he omits the use of the article 'the' from the place where it should be used. It is also caused by simplifying the use of the article by omitting it. Yet, he doesn't make any error in the addition of the article ' $a / a n$ ', but he makes error in the addition of article 'the' where he writes it on the place it shouldn't belong to. It is caused by overgeneralization, where he attempts at putting the article in a possible place but it isn't correct.

Table 4: Article error - STIE Eka Prasetya

\begin{tabular}{|c|c|c|c|c|c|}
\hline Initial & Category & Error Form & Amount & Source \& Cause & Correct Form \\
\hline \multirow[t]{8}{*}{ NIN } & $\begin{array}{l}\text { Omission of } \\
\text { 'a/an' }\end{array}$ & $\begin{array}{l}\text { through 1library } \\
\text { research and } \\
\text { 2field research }\end{array}$ & \multirow[t]{2}{*}{6} & \multirow{2}{*}{$\begin{array}{l}\text { Intra-language } \\
\text { error } \\
\text { Simplification by } \\
\text { omitting article } \\
\text { needed }\end{array}$} & $\begin{array}{l}\text { through }^{1} a \\
\text { library research } \\
\text { and }{ }^{2} a \text { field } \\
\text { research }\end{array}$ \\
\hline & & $\begin{array}{l}\text {...has a positive } \\
\text { and } \\
4,5,6 \text { significant } \\
\text { effect... }\end{array}$ & & & $\begin{array}{l}\text {...has a positive } \\
\text { and } 4,5,6 a \\
\text { significant } \\
\text { effect... }\end{array}$ \\
\hline & \multirow[t]{4}{*}{$\begin{array}{l}\text { Omission of } \\
\text { 'the' }\end{array}$} & $\begin{array}{l}\text {...unit are } \\
{ }^{1} \text { guests from PT. } \\
\text { Karya Cipta }\end{array}$ & \multirow[t]{4}{*}{5} & \multirow{4}{*}{$\begin{array}{l}\text { Intra-language } \\
\text { error } \\
\text { Simplification by } \\
\text { omitting article } \\
\text { needed }\end{array}$} & $\begin{array}{l}\text {...unit are }{ }^{1} \text { the } \\
\text { guests from PT. } \\
\text { Karya Cipta }\end{array}$ \\
\hline & & $\begin{array}{l}\text {...were }{ }^{2} \text { guests } \\
\text { from PT. Karya } \\
\text { Cipta }\end{array}$ & & & $\begin{array}{l}\text {... were }{ }^{2} \text { the } \\
\text { guests from PT. } \\
\text { Karya Cipta }\end{array}$ \\
\hline & & $\begin{array}{l}\text {...based on } \\
{ }^{3} \text { research } \\
\text { objectives... }\end{array}$ & & & $\begin{array}{l}\text {...based on }{ }^{3} \text { the } \\
\text { research } \\
\text { objectives... }\end{array}$ \\
\hline & & $\begin{array}{l}\text {...to solve } \\
{ }^{4} \text { problems and } \\
\text { prove } \\
{ }^{5} \text { hypotheses... }\end{array}$ & & & $\begin{array}{l}\text {...to solve }{ }^{4} \text { the } \\
\text { problems and } \\
\text { prove }{ }^{5} \text { the } \\
\text { hypotheses... }\end{array}$ \\
\hline & $\begin{array}{l}\text { Addition of } \\
\text { 'a/ } \mathrm{an}^{\prime}\end{array}$ & 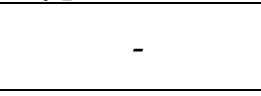 & - & - & 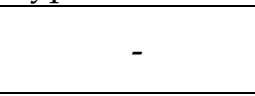 \\
\hline & $\begin{array}{l}\text { Addition of } \\
\text { 'the' }\end{array}$ & $\begin{array}{l}\text {... the effect of } \\
{ }^{1} \text { the Price, } \\
\text { Online }\end{array}$ & 1 & $\begin{array}{l}\text { Intra-language } \\
\text { error } \\
\text { Overgeneralization }\end{array}$ & $\begin{array}{l}\ldots \text { the effect of } 1 \\
\text { Price, Online } \\
\text { customer ... }\end{array}$ \\
\hline
\end{tabular}


Grammatical Errors in Thesis Abstracts Written by the Undergraduate Students of...

\begin{tabular}{|c|c|c|c|c|c|}
\hline Initial & Category & Error Form & Amount & Source \& Cause & Correct Form \\
\hline & & istomer ... & & he use of article & \\
\hline
\end{tabular}

From the article errors written by student NIN, it is found that he misses using the article ' $a / a n / t h e^{\prime}$ on the place where they belong to. It happens because he simplifies the use of the articles. He makes no error in the addition of ' $a / a n$ '. But he once makes an error by adding the article 'the' on the unnecessary place of the clause. It is because of his action to overgeneralize the use of the article ' $i t$ ', but it's incorrect.

Table 5: Total quantification of grammatical error

\begin{tabular}{|c|c|c|c|c|c|}
\hline \multirow{3}{*}{ Type of Errors } & \multicolumn{4}{|c|}{ Number of Error Occurrences } & \multirow{3}{*}{ Amount } \\
\hline & \multicolumn{2}{|c|}{$\begin{array}{c}\text { STIE } \\
\text { Eka Prasetya }\end{array}$} & \multicolumn{2}{|c|}{$\begin{array}{c}\text { STIM } \\
\text { Sukma Medan }\end{array}$} & \\
\hline & Inter* & Intra* & Inter* & Intra* & \\
\hline \multicolumn{6}{|l|}{ The use of SVA } \\
\hline $\begin{array}{l}\text { - The Use of Number Agreement } \\
\text { Error }\end{array}$ & 1 & 8 & 0 & 1 & 10 \\
\hline - The Use of Tense Agreement Error & 3 & 27 & 0 & 50 & 80 \\
\hline \multicolumn{6}{|l|}{ The use of Article 'a/an/the' } \\
\hline - Omission of ‘a/an' & 0 & 35 & 0 & 13 & 48 \\
\hline - Omission of 'the' & 0 & 83 & 0 & 70 & 153 \\
\hline - Addition of 'a/an' & 0 & 0 & 0 & 1 & 1 \\
\hline \multirow[t]{2}{*}{ - Addition of 'the' } & 0 & 5 & 0 & 3 & 8 \\
\hline & & & \multicolumn{2}{|c|}{ Total of Error } & 300 \\
\hline
\end{tabular}

Inter $^{*}=$ inter-language error; Intra ${ }^{*}=$ intra-language error

Table 5 above shows the final quantification of the data analysis. These numerical data are the key to the discussion of the research findings in the next section.

\section{DISCUSSION}

The results of data analysis have revealed that the grammatical errors within the use of SVA and the use of articles remain to appear in quite vast amounts. They are obtained after the data are converted into number form.

The category of SVA error in the abstract written by the undergraduates of Sekolah Tinggi Ilmu Manajemen Sukma Medan is significant to reveal the cause of the errors, in which all of the grammatical errors found in this data set are caused by the intra-language error. As a sign of the lack of knowledge of L2 structure, the intra-language error indicates that the students who write the abstract might not have complete knowledge of the English language structure and adequate ability to apply the standardized English grammar. 
The category of SVA error in the abstract written by the graduates of Sekolah Tinggi Ilmu Ekonomi Eka Prasetya explains that the entire article errors are caused by the intra-language error. The findings from this data reveal that in this data set, the sources of errors are caused by both interlanguage and intra-language errors. In other words, the grammatical errors found in this data set are not only caused by the interference of L1.

Eventually, the results of the entire data analysis show that the most predominant errors are ordered as followings; 153 omissions of article 'the' $(51 \%) ; 80$ errors of the tense agreement $(26,7 \%) ; 48$ omissions of article ' $a / n$ ' (16\%); 10 errors of the number agreement (3,3\%); 8 additions of article 'the'; and 1 addition of article 'a/an'. Besides, within the total number of 300 errors, the intra-language causes 296 errors (88\%), and the inter-language causes only 4 errors (12\%). By seeing these results, it can be inferred that the negative interference of learners' L1 doesn't significantly influence the errors they make in the undergraduate thesis abstracts, moreover, it is the lack of L2 knowledge does. In line with this finding, the research conducted by Dinamika and Hanafiah (2019) find that syntactical errors made by the students of the English Department of University of Sumatera Utara also had been affected by the L2 factors. In addition, Burhanuddin (2020:30) the errors in the questionnaire instruments which are written by students of the English Department of IAIN Pekalongan were caused by the students' incomplete L2 acquirement.

To follow-up the discussion section, thus the last procedure of the EA method, the remedial actions are required to be taken up. These actions are typically constructive suggestions that the researcher intentionally directs to the EFL learners, the English instructors at the two research locations, and the syllabus developers.

\section{Remediation in Subject-verb Agreement Error}

The results of the analysis show that the tense agreement error occurs for 80 times that exceeds the number of agreement errors which is only 10. Therefore, it also presents a new finding that both students of STIM Sukma Medan and STIE Eka Prasetya still make errors in using the tense and number agreement. However, the researcher attempts at taking part in this issue by giving several remedial actions to do.

To the EFL learners, in this research refer to students, who write the undergraduate thesis abstract, it is compulsory for them to remember the verb changes according to its time signal. In other words, they should comprehend that when a context of the time in a clause changes, then the verb should follow. In most cases found in this analysis are that the students are less aware of this process of verb change, so forth they make errors in the tense agreement. Meanwhile, in the use of number agreement, they make 
fewer errors. Yet, they still need to pay attention to the agreement between the form of the subject, whether it is a singular or plural form, in which the aux. verb or to be shall follow the initial form of the subject. However, practice on using SVA is important to do regularly and needs to proofread the abstracts before submitting it.

The researcher suggests the English instructors of STIM Sukma Medan and STIE Eka Prasetya do as follows; to introduce the students to the undergraduate thesis particularly to the abstract section; to encourage the students to learn the use of SVA directly from the available undergraduate thesis; to give the students opportunities to self-analyze the correctness of the English language used in the abstract and mark the error they assume; to guide them correcting the errors that they have assumed by explaining the right SVA rules, and to give the students time to practice more on the use of SVA.

To the syllabus or course design developer of each college, the researcher has several to suggest; need to review the success of the English syllabus that has been used along this time due to the defined criteria; take out the proper step due to the findings of this research, and to provide probably a short course to the students in writing thesis abstract before attempting to submit it as the final graduation requirement. Therefore, those suggested remedial actions can be done to minimize the SVA error in the future.

\section{Remediation in Article Error}

The total number of article errors accounts for the most error of this research that amounts up to 210 occurrences. Moreover, all of the errors are caused by intra-language errors. It shows that even though the article is a small part of speech in the English language, but it still appears to be an error in the application. Therefore, the researcher suggests the students learn more about the article units and their function. They also need to know when to omit or add an article on the phrase or clause they write. Moreover, if they make an error in the use of an article, it can be a deal to a published paper. They may also take a sight on the previous abstracts at the library and open a group discussion to examine the errors in the abstracts. However, the students need to practice more on using the article on their writings.

To the English instructors, the researcher may offer them the interactive activities to do with the students, for instance, making a small group discussion, having direct learning by examining the available thesis as the source of study instead of only teaching the students the grammar of English on the whiteboard, asking each student to write a topic-free essay and exchanging it with other students so they can self-correct mate's work, 
and engaging them to practice regularly not only when they need to write a thesis abstract.

At last, to the syllabus or course design developer, the researcher attempts at telling them to analyze the needs of the students in their institution first, of course, this activity takes time, but hopefully, it will work successfully. What the researcher means here is, just provide the students with what they exactly need instead of providing them the materials which are not suitable for their needs though. The syllabus or course design developer also needs to update the syllabus that is still used, whether it is still usable or not for the current issue of the students' researches. Because, there are a lot of outdated syllabuses that are still used until now, the researcher finds. In this case, the work of the syllabus developer is the key because it bridges between the college policy and the students' knowledge. In other words, a syllabus that is designed due to the students' actual needs will succeed the entire teaching-learning purpose.

\section{CONCLUSION AND SUGGESTION}

The data of this research are the English grammatical errors which are taken from twenty undergraduate thesis abstracts written by the students of management studies of Sekolah Tinggi Ilmu Manajemen Sukma Medan and Sekolah Tinggi Ilmu Ekonomi Eka Prasetya. The data are analyzed by using the Error Analysis Method which is arranged by Gass and Selinker. After the entire data is analyzed, it is obtained that categories of the grammatical errors found are the subject-verb agreement in terms of tense agreement and number agreement, and the article ' $a / a n / t^{\prime} e^{\prime}$. The numerical findings are as follows; the tense agreement error amounts to 80, the number agreement error amounts to 10, the omission of article a/ an amounts to 48, the omission of article 'the' amounts to 153, the addition of article 'a/an' amount to 1 and the addition of article 'the' amount to 8. So forth, the total grammatical errors found in this research are 300 errors. Meanwhile, there are two sources of the grammatical error; they are inter-language error and intralanguage error. Yet, there are four factors that cause the grammatical error namely, indeterminacy, inconsistency, simplification and overgeneralization. Therefore, by seeing the findings of the research, the researcher manages at giving several constructive suggestions to the EFL learners, English language instructor and the syllabus or course design developer.

Although the Error Analysis is an old field of second language acquisition field, but it remains significant with the needs of today's L2 learning. It can be seen from the increasing number of researches on EA every year. Even more non-English speaking countries conduct research on EA to examine the output of English language learners in their countries. Then it proves that the EA is still an adequate theory to reveal L2 learners' 
errors. Besides, the scope of EA is quite wide-scale to explore, it is not only limited in the written field, but also to the oral field. Yet, there are a lot of extents of language that can be analyzed with EA, because the main point of using EA is to contrast the L2 learners' knowledge and ability to the L2 structure of language.

\section{ACKNOWLEDGEMENT}

This research was fully funded and supported by the Directorate of Research and Community Service, Directorate General of Research and Development Ministry of Research, Technology and Higher Education under the Ministry of Research and Technology - Republic of Indonesia, with the scheme of Penelitian Dosen Pemula year of 2019-2020. The researcher also would like to thank to Mrs. Wardayani, M.Si, the Chairwoman of STIM Sukma and Mrs. Dr. Sri Rezeki, M.Si, the Chairwoman of STIE Eka Prasetya for providing very crucial data and cooperative assistances.

\section{REFERENCES}

Burhanuddin, Ahmad. (2020). Error Analysis of English Sentences Written by Indonesian College Students. Jurnal Lingua Idea. 11. 30-43. 10.20884/1.jli.2020.11.1.2154.

Corder, S.P. (1981). Error Analysis and Interlanguage. Oxford: Oxford University Press.

Dinamika, S., Hanafiah, R. (2019). Syntactical Error Analysis on Report Text. JOALL (Journal of Applied Linguistics E Literature). Vol. 4 No. 2. 120-129. ISSN: 2502-7816.

Gass, S.M. and Selinker, L. (2008). Second Language Acquisition: An Introductory Course. New York: Routledge Taylor and Francis Group.

Kusumawardhani, P. (2017). The Analysis of Errors of Omission in English Narrative Composition Made by EFL Students. Journal of English Language and Education. Vol. 3. No. 2, 84-96. December 2017. ISSN: 2460-7142.

LLDIKTI Wilayah I. (2019). Data Perguruan Tinggi LLDIKTI Wilayah I. Retrieved from https://forlap.ristekdikti.go.id/perguruantinggi/. Accessed on May 2019.

Mackey, A. and Gass, S. M. (2005). Second Language Research: Methodology and Design. London: Lawrence Erlbaum Associates Publishers.

Merizawati, H. (2019). An Error Analysis in Paper Presentations: A Case Study of Indonesian EFL Learners. Linguists: Journal Of Linguistics and Language Teaching, [S.l.], v. 4, n. 2, p. 71-103, March 2019. ISSN 26565765. 
Porte, G. K. (2002). Appraising Research in Second Language Learning: A practical approach to critical analysis of quantitative research. John Benjamins Publishing Company: Amsterdam.

Richards, J.C, ed. (1972). Error Analysis: Perspective on Second Language Acquisition. New York: Longman.

Singh, Y.K. (2006). Fundamental of Research Mehodology and Statistics. New Age International (P) Ltd., Publishers: New Delhi.

Touchie, H.Y. 1986. Second Language Learning Errors. Their Types, Causes And Treatment. JALT Journal. Volume 8 (No. 1:1986): 75-80.

Yuned, et.al. (2015). Thematic Progressions of the 2015 TEFLIN Article Abstracts in Applied Linguistics. JOALL (Journal of Applied Linguistics \& Literature). Vol. 1 No. 2. 95-115. ISSN: 2502-7816. 